Article

\title{
Using a Geospatial Model to Relate Fluvial Geomorphology to Macroinvertebrate Habitat in a Prairie River-Part 1: Genus-Level Relationships with Geomorphic Typologies
}

\author{
Anna G. N. Meissner ${ }^{1}{ }^{*}$, Meghan K. Carr ${ }^{1}$, Iain D. Phillips ${ }^{2}$ and Karl-Erich Lindenschmidt ${ }^{1}$ \\ 1 Global Institute for Water Security, University of Saskatchewan, 11 Innovation Boulevard, Saskatoon, \\ SK S7N 3H5, Canada; meghan.carr@usask.ca (M.K.C.); karl-erich.lindenschmidt@usask.ca (K.-E.L.) \\ 2 Water Security Agency, Innovation Place, 101-108 Research Drive, Saskatoon, SK S7K 3R3, Canada; \\ iain.phillips@wsask.ca \\ * Correspondence: anna.meissner@usask.ca; Tel.: +1-306-966-2825
}

Academic Editor: Miklas Scholz

Received: 31 October 2015; Accepted: 27 January 2016; Published: 29 January 2016

\begin{abstract}
Modern river ecosystems undergo constant stress from disturbances such as bank stabilization, channelization, dams, and municipal, agricultural, and industrial water use. As these anthropogenic water requirements persist, more efficient methods of characterizing river reaches are essential. Benthic macroinvertebrates are helpful when evaluating fluvial health, because they are often the first group to react to contaminants that can then be transferred through them to other trophic levels. Hence, the purpose of this research is to use a geospatial model to differentiate instream macroinvertebrate habitats, and determine if the model is a viable method for stream evaluation. Through the use of ArcGIS and digital elevation models, the fluvial geomorphology of the Qu'Appelle River in Saskatchewan (SK) was assessed. Four geomorphological characteristics of the river were isolated (sinuosity, slope, fractal dimension, and stream width) and clustered through Principle Component Analysis (PCA), yielding sets of river reaches with similar geomorphological characteristics, called typologies. These typologies were mapped to form a geospatial model of the river. Macroinvertebrate data were aligned to the locations of the typologies, revealing several relationships with the fluvial geomorphology. A Kruskal-Wallis analysis and post hoc pairwise multiple comparisons were completed with the macroinvertebrate data to pinpoint significant genera, as related to the geospatial model.
\end{abstract}

Keywords: macroinvertebrates; fluvial geomorphology; fractal dimension; geomorphic typologies; sinuosity; Saskatchewan

\section{Introduction}

The study of aquatic macroinvertebrates within fluvial systems can reveal information about water quality $[1,2]$, interactions with other trophic levels [3,4], as well as anthropogenic influences on river health $[5,6]$. Traditional methods used to examine the fluvial benthic community rely on fieldwork and data collection; as such, the methods can be time consuming, labour intensive, and expensive. More efficient methods have emerged for studying macroinvertebrates, but these are often tailored to the interests of specific studies. This could be a result of the sheer vastness of fluvial ecosystems and macroinvertebrates. The dynamic nature of river ecosystems and the highly diverse macroinvertebrate community commonly found in fluvial ecosystems make it difficult to study them as a whole. Therefore, studies often choose to organize macroinvertebrate data collection and analysis by metahabitat (i.e., riffle, pool, run) or instream habitats that are classified using physical traits. Methods 
used in studies related to analyzing physical habitat include the IndVal method for communities [7-9], analyses using the species-based habitat suitability criteria (HSC) that are subsequently incorporated into habitat simulation models [10-13], the fairly new random forests nonparametric method $[9,14]$, and many more. These methods relate collected macroinvertebrate data back to the river metahabitats for correlation. Other studies focus on certain groups of macroinvertebrates, such as the more sensitive Ephemeroptera, Plecoptera, and Trichoptera (EPT) orders [2,4], or macroinvertebrates found in niche stream habitats (e.g., rock substrates). Methods for stone substrate macroinvertebrate studies began using labour-intensive field collection, but modern methods, such as surface area estimation, have since been developed $[15,16]$. Methods used to understand macroinvertebrates within large fluvial systems that do not rely on field data have not been widely developed.

Creating more effective and efficient methods of studying macroinvertebrates is a worthy goal, because a better understanding of macroinvertebrates leads to increased knowledge of the watershed as a whole. Macroinvertebrates are the food source for many trophic levels, are often the first to respond to ecosystem degradation, and can be the point of contaminant uptake [17,18]. In the case of contaminants, macroinvertebrates can pass harmful substances to those that feed on them, like fish and birds, creating a pattern of bioaccumulation. Contaminants can be linked to geomorphology as well; fluvial geomorphology directly influences instream flow and subsequently the distribution of sediment, creating the many instream habitats macroinvertebrates live in $[19,20]$. Consequently, the sediment type and distribution (driven by geomorphology) directly relates to many dangerous substances that macroinvertebrates may ingest. Clay, for instance, has such a small grain size that it is negatively charged, making bonds with the positively charged metals much easier [19]. The metals derived from industrial processes, such as mining, increase aquatic metal concentrations (i.e., mercury, cadmium, copper, zinc, lead) as they settle and bond to the clay in the river [19,21]. Macroinvertebrates living in this clay can ingest these metals, leading to bioaccumulation in later trophic levels. In the case of the more toxic metals, like mercury, bioaccumulation can reach terrestrial consumers, including humans [21]. Understanding fluvial geomorphology and instream macroinvertebrate habitats is vital to further understanding dangerous bioaccumulation and contaminant relations.

The River Continuum Concept (RCC) exemplifies the notion of viewing rivers as predictable systems assuming that macroinvertebrate habitat is organized by linear location [22]. The RCC has been disputed for not applying to real and complex fluvial environments. Instead of concepts like the RCC, spatial dynamics and geomorphological processes at a local-level are widely accepted as the driving factors behind instream habitats and communities [23,24]. Furthermore, fluvial geomorphology has long been associated with instream biodiversity, meaning that river macroinvertebrates are influenced by river structure $[4,25,26]$. Aquatic macroinvertebrate habitat selection is influenced by local features, which result from extensive geomorphological and hydrological processes [20,27]. Through classifying reaches of the river with similar geomorphological characteristics (typologies), rather than by metacommunities, patterns in macroinvertebrate habitat can be pursued. This information could then be applied to rivers from which data are difficult to collect, due to their large spatial extent [28]. Therefore, creating a model of geomorphological characteristics within a river is a novel method for identifying macroinvertebrate habitat more broadly. Unlike the linear RCC, the use of geomorphic typologies acknowledges the fact that diverse instream habitats, resulting from channel morphology interacting with dynamic hydrological processes, are the reality of modern rivers [29]. Four geomorphological characteristics (sinuosity, stream width, fractal dimension, and slope) have been focused on, in the creation of the geospatial model for this study. These characteristics are all affected by anthropogenic influences in modern rivers. Understandably, channelization changes the geomorphology of a river substantially. For the purposes of flood control, land drainage, or erosion mitigation, the channel may be straightened, realigned, or enlarged [30]. Other modifications include dredging, building embankments, bank stabilization, and, of course, dams [30]. These drastic anthropogenic alterations are examples of how the geomorphological characteristics studied here are certain to change with increased societal use of rivers. In this study, valuable macroinvertebrate 
data were analyzed in relation to a geomorphological model of the Qu'Appelle River, Saskatchewan. We hypothesize that geomorphic typologies within the river will reveal significant relationships between geomorphology and the benthic macroinvertebrate community in a fluvial system. The study concentrates on macroinvertebrates at the genus level; the data set was tested to determine which genera contain significant relationships to geomorphological typologies. These genera were then the focus of further study.

\section{Methods}

\subsection{Study Site}

The Qu'Appelle River flows in the Saskatchewan plains region of Canada, which is home to sweeping river valleys, wide lake plains, ground moraines, and large spillways prone to flooding [31]. The $\mathrm{Qu}$ 'Appelle is a river and lake network; it begins at the Qu'Appelle Dam at Lake Diefenbaker and flows toward the Manitoba border (Figure 1). The basin's dynamic geomorphology provides diverse habitats for many species, including more than 30 rare and endangered animal and plant species. Among these species are bigmouth buffalo fish, loggerhead shrike, and smooth arid goosefoot, all relying on the varied landscape and water within the valley [32]. The Qu'Appelle River Watershed provides water to several municipalities, including two cities (Moose-Jaw and Regina), whose combined population could reach half a million by the year 2050 [33]. Besides municipal water use, the system accommodates many local interests including recreational, agricultural, industrial, and environmental requirements [34]. Water quality and supply are fundamental for the Qu'Appelle system and its residents, as it boasts a diverse fish assemblage and active recreational fishery. The Qu'Appelle River Watershed area also hosts a large amount of Saskatchewan potash production, for which water is essential; demand for water will continue to rise in this region as potash mining and other industrial practices expand [33,35]. Channelization has occurred from the outlet at the Qu'Appelle River Dam to about 32 km downstream; the remaining river stretches' freely-developed and meandering expanses are prone to flooding, erosion, sloughing, silting, as well as water quality and quantity issues [31,33]. Heavy reliance on water by people and industry within the watershed necessitates sustainable and effective monitoring and protection efforts for the Qu'Appelle River.

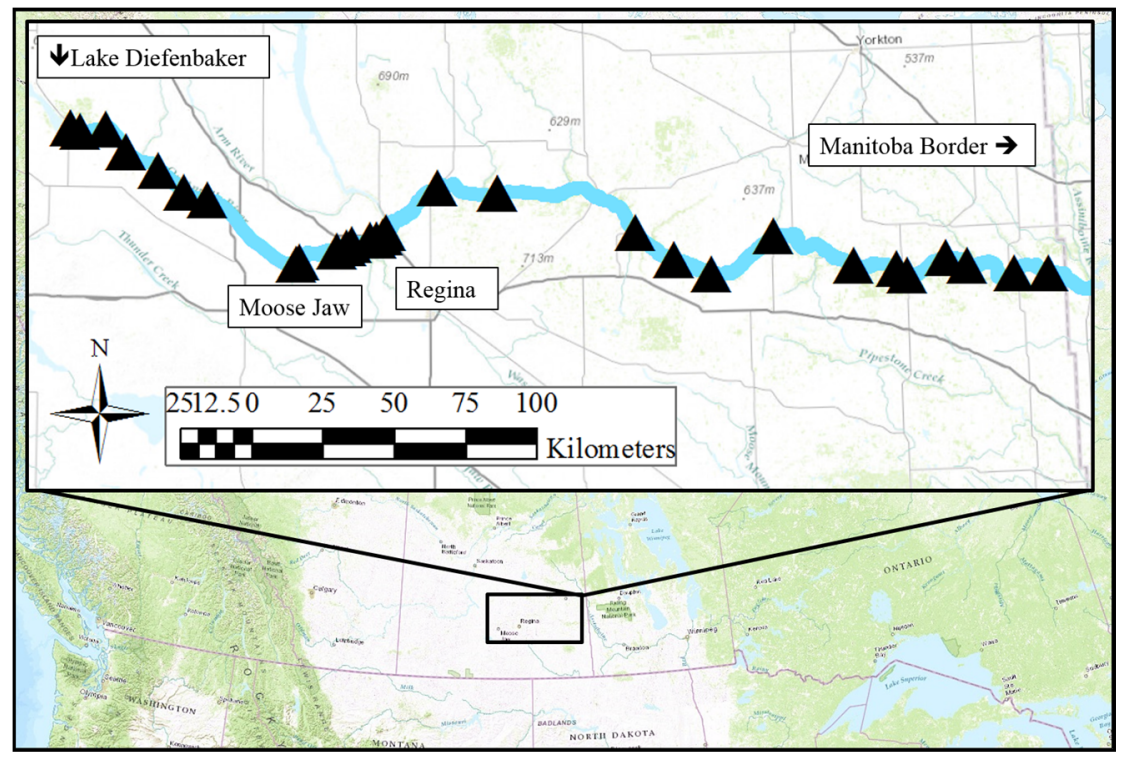

Figure 1. Location of the $\mathrm{Qu}$ 'Appelle River, the river centerline, and the 35 macroinvertebrate sampling sites. 


\subsection{Geospatial Factors}

In order to characterize the geospatial nature of the river, four characteristics were selected as points of comparison; these were stream width, sinuosity, fractal dimension, and slope. These characteristics were chosen because they provide a good representation of the watershed geomorphology. Other studies wishing to use the geospatial model delineated in this study could include a variety of parameters, such as average flow, depth, or water temperature to create a different river profile. First, the centerline of the river was delineated through the use of river polygons, and points placed along the line every $50 \mathrm{~m}$. At each point, transects were placed, crossing the polygon from bank to bank (Figure 2). The 1:50,000 digital elevation model (DEM) data (Source: Department of Natural Resources Canada) provided elevation at each bank point using Geographic Information System (GIS) software, and its average elevation linked to the point at the centerline. Finally, at each centerline point, the four geospatial characteristics were extracted [28]. Slope, stream width, sinuosity, and fractal dimension were calculated and extracted at each centerline point delineated. Slope is simply the level of vertical drop in river bed elevation at each $50 \mathrm{~m}$ point [30]. Stream width is the length of the transect at each centerline point (Figure 2). The minimum stream width recorded at the centerline points was $6.8 \mathrm{~m}$, the maximum was $2226.9 \mathrm{~m}$, and the average was $168.7 \mathrm{~m}$. The commercial software package Mathcad ${ }^{\circledR}$ v.15 (PTC, Inc., Needham, MA, USA) [36] was used in calculating both the sinuosity and fractal dimension of the river reaches. For the sinuosity, a marginally larger scale was used than for the stream width and slope; 40 adjacent points were used (20 upstream and 20 downstream of each centerline point). Sinuosity, or how much a river meanders, is a significant fluvial characteristic because it impacts how water flows, how sediment is distributed, and ultimately how local instream habitats form [37]. Sinuosity is also defined as the interchange between the valley slope and the river slope [38], or between the length of the valley (shortest possible distance) and the length of the river. In addition to different definitions of sinuosity, various terms are used to describe the spectrum of sinuosity values $(S)$. These include $S=1$ for a linear (straight) reach, and in succession of increasing sinuosity, elongated, oscillating, tortuous, and lastly meandering with $S>2[39,40]$. Rivers with high sinuosity also have increased bed material of a smaller grain size (i.e., silt, clay) [41]. Where channels meander, augmented bank erosion transpires, thus providing a higher load of easily transferred (finematerials) sediment to the stream [19], with $S>1.5$ indicating a riverbed containing over $92 \%$ fine textured material [38]. Within the Qu'Appelle River, $63 \%$ has a sinuosity of $S>1.5$, suggesting that the riverbed has a share of both coarse and fine materials, corresponding to the till blanket that comprises much of the surficial geology of the river basin. Sinuosity, in our study, is defined as the length of a river reach divided by the shortest distance between the reach end points (a straight path). A sinuosity score of one represents a straight channel, and $>1$ is a meandering one [37,42].



Figure 2. Delineation of a river polygon, centerline, points placed on the line every $50 \mathrm{~m}$, and transects through each point that cross the polygon to both banks.

Analogous to sinuosity, but at a greater scale, fractal dimension represents how much Euclidean space a river reach fills. Different than sinuosity, fractal dimension quantifies form and indicates both the number and amplitude of meander changes within a channel length, at a larger order of 
magnitude [42-44]. As a tool, fractal dimension is helpful for understanding patterns within fluvial systems at a more expansive, geological scale [28,42]. Fractal dimension is uniquely suited to the complex and irregular nature of a river. It uses a minimum value of one and a maximum of two; in linear river systems, the higher the value is, the more space-filling it is within the drainage area [43]. To calculate fractal dimension, the number of centerline points contained within a $40 \mathrm{~km} \times 40 \mathrm{~km}$ window moving along the river was used. These scales were selected, as they were the values where the peak variation was calculated. Once these geospatial characteristics were found, a Principal Component Analysis (PCA) was performed with the statistical package R 2.15 .2 [45] to pinpoint groups (typologies) of similar characteristics [28]. The PCA makes a large dataset more manageable by identifying patterns within it and reducing its dimensionality [46]. To improve normality of the dataset while considering the high incidence of zero and minute slope values, the dataset was $\log _{10}+1$ transformed prior to PCA. The explained variance of principal components (PC) one through four was $49 \%, 24 \%, 14 \%$ and $13 \%$, respectively. Only the first two principal components (accounting for $73 \%$ cumulative variance) were used to derive typologies as, following the Kaiser-Guttman rule, eigenvalues for components 3 and 4 were far less than 1 ( 0.57 and 0.52, respectively). At each centerline point, binary values were assigned to the scores associated with PCs one and two, 1 for positive PC scores and 0 for negative PC scores. Binary values were then summed, resulting in four unique typologies. Each of the four typologies was designated a colour, which was then matched to the corresponding centerline points (Figure 3).

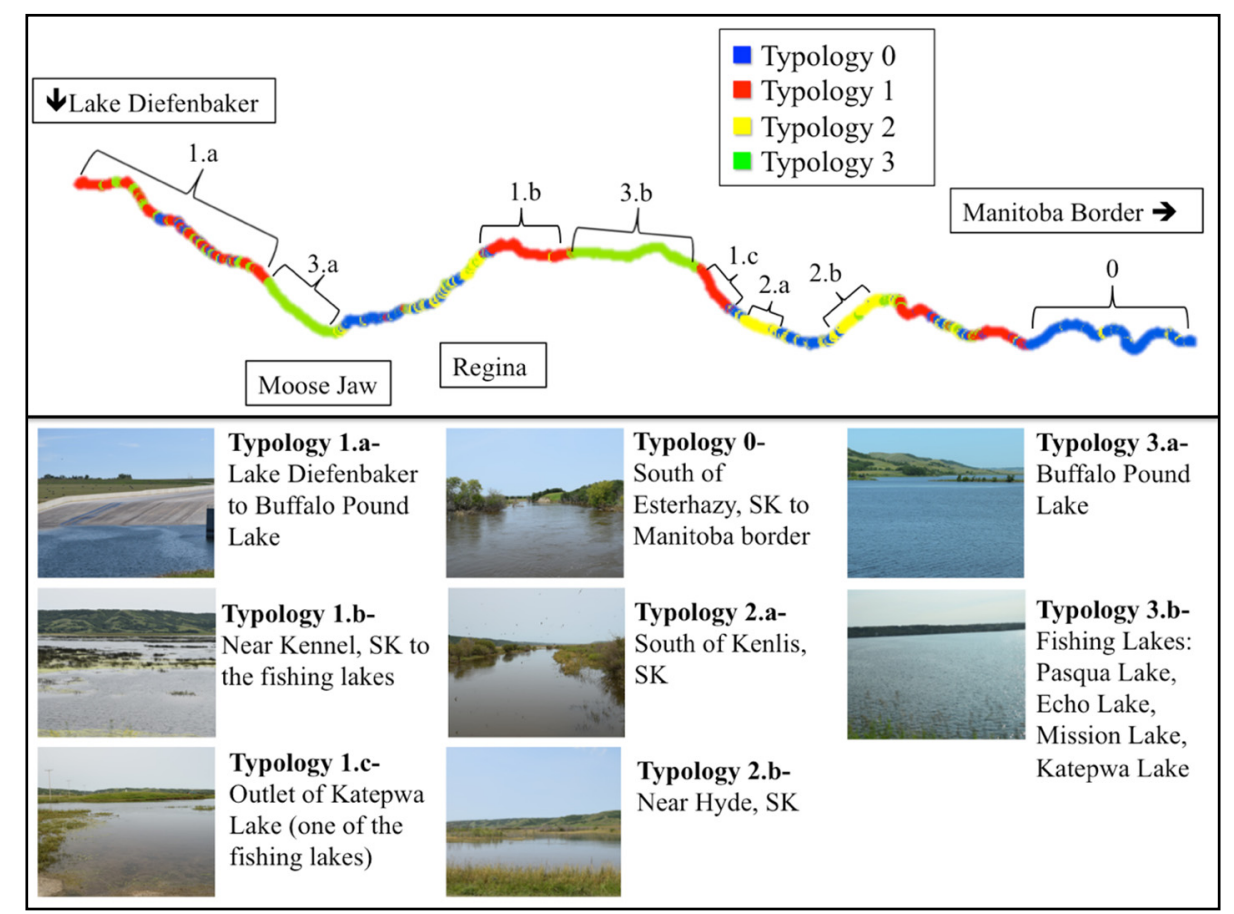

Figure 3. Delineated Typologies on the Qu'Appelle River centerline, key reaches labeled, site pictures corresponding to the key reaches.

\subsection{Macroinvertebrate Sampling}

Benthic macroinvertebrate collection took place between 2006 and 2009 along the Qu'Appelle River, Saskatchewan. The macroinvertebrate collection and compilation of the database used in this study were completed before the delineation of the geospatial model, and separate from this study. Optimally, the typologies would have been delineated prior to sampling, so that sites could be selected with a more even distribution amongst typologies. The sampling method used was the travelling kick and sweep (TK \& S) technique, a standardized sampling method that permits the comparison 
of communities within similar habitats between sites. Sampling sites were selected to accommodate for road access, at a pre-determined minimum river distance of $10 \mathrm{~km}$ between sites. During this process, a bank-to-bank transect is sampled at five different positions and combined into one composite sample. Since the TK \& S method involves sampling along transects, the subsequent data set spans an array of habitats found within a reach. A D-frame net (500 $\mu \mathrm{m}$ mesh), positioned downstream from the person collecting the sample, was used in the present study. As the net is held, the area $(\sim 30 \mathrm{~cm} \times 30 \mathrm{~cm})$ is kicked to $\sim 5 \mathrm{~cm}$ depth for a $10 \mathrm{~s}$ time period at each of the five positions along all transects. All the sampled sites were similar prairie reaches that were straight, slow flowing, and with no riffles. Substrate was generally soft silt, with less frequent and small patches of cobble and vegetation on bank positions. Ultimately, our objective was to employ a standardized method of collecting benthic macroinvertebrates in comparable habitats across all sites, to ensure the dominant communities for major habitat features would be represented. Although the TK \& $S$ method does not guarantee that all taxa present at a sampling site are collected, we feel the most dominant assemblages and habitat features have been adequately characterized. The collected macroinvertebrate samples were saved in $80 \%$ ethanol and subsequently moved to the laboratory, in which $7 \times$ magnification was used to separate the macroinvertebrate samples from any organic material. Identification of the macroinvertebrates using keys for North America [17] and Western Canada, when available [47-49], was then completed. The Water Security Agency of Saskatchewan Invertebrate Voucher Collection (Saskatoon, SK, Canada), and the Royal Saskatchewan Museum (Regina, SK, Canada) hold the voucher series from this sample. Taxa occurrence records from the study were submitted to the Saskatchewan Conservation Data Centre with the Ministry of Environment.

\subsection{Statistical Analysis}

Using the R 3.1.2 statistical software [45], a Kruskal-Wallis analysis of variance on ranks was performed on the macroinvertebrate genera, to determine whether their distribution yielded statistical differences between the 4 typologies. In the event of a significant outcome ( $p$ value $\leqslant 0.05$ ), post hoc pairwise multiple comparisons were completed. A one-tailed Dunn test with Bonferroni $p$ value correction for multiple paired tests was used, and graphical analyses were accomplished through use of the statistical program R 3.1.2 [45]. The data set was narrowed down for the analysis, to include only genera with $\geqslant 30$ individuals sampled and collected in $>9 \%(3+)$ of sampling sites. This test can be used to understand whether the mean ranks are the same or different in all the groups, when dealing with an unequal sampling distribution among typologies.

\section{Results and Discussion}

The PCA scores (colour coded by typology) and variable vectors are plotted in Figure 4, with principal component one on the $x$-axis, and component two on the $y$-axis. This biplot is used to surmise the overall relationships between the four geomorphological variables (sinuosity, slope, fractal dimension, channel width), as well as their relationships within the distinct typologies (Figure 4).

Principal components one and two account for $73 \%$ of the total variation found in the dataset. Normalized values of sinuosity, slope, fractal dimension, and channel width were also charted in density plots. The plots were used to observe the qualitative contribution of these four geomorphological variables to each individual geomorphic typology based on absolute means (Figure 5).

The subsequent relationships established for all four typologies to sinuosity, slope, fractal dimension, and channel width are summarized in Table 1 . Typology 0 is positively related to both slope and fractal dimension and negatively related to width. Typology 1 is positively related to slope, yet negatively related to all the other variables. Typology 2 is positively related to both sinuosity and fractal dimension, but negatively related to width. Typology 3 is negatively related to all variables, except for width. 


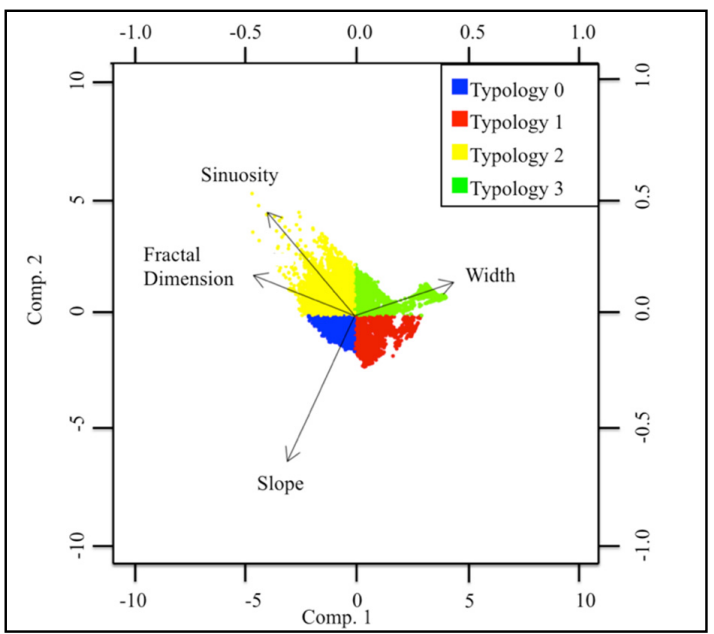

Figure 4. Biplot of PCA scores (colour coded by typology) and the four variable vectors: sinuosity, slope, fractal dimension, and stream width, plotted in relation to principal components 1 ( $x$-axis, $49 \%$ variation) and 2 (y-axis, $24 \%$ variance).

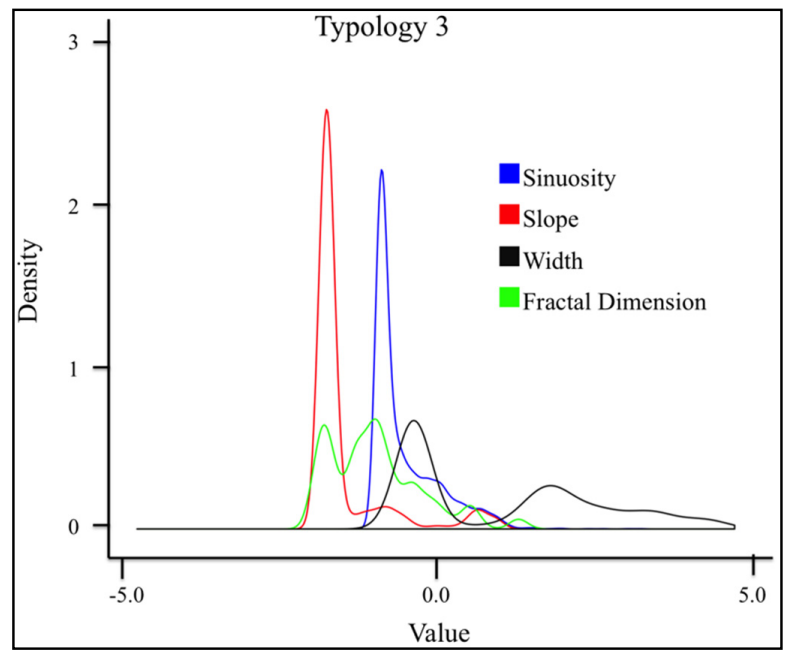

Figure 5. Density plot of the normalized values of channel sinuosity, slope, fractal dimension and width exemplified in Typology 3.

Table 1. The qualitative contribution of variables to each typology, resulting from the principal component analysis. $(-)=$ negative relationship, $(+)=$ positiverelationship, $(0)=$ no discernable relationship.

\begin{tabular}{ccccc}
\hline Typology & Sinuosity & Slope & Fractal Dimension & Width \\
\hline 0 & 0 & + & + & - \\
1 & - & + & - & - \\
2 & + & 0 & + & - \\
3 & - & - & - & + \\
\hline
\end{tabular}

River stretches designated as Typology 0 are therefore characterized by more narrow regions of high slope and fractal dimension. Typology 1 is associated with narrow areas of high slope, low fractal dimension, and sinuosity. The features related with Typology 2 are highly sinuous regions with high fractal dimension values, yet are still narrow. Finally, Typology 3 is associated with wide reaches that are less sinuous, with low slope and fractal dimension values. 


\subsection{Macroinvertebrate Survey}

Macroinvertebrate sampling occurred at 35 sites along the $\mathrm{Qu}^{\prime}$ Appelle River, resulting in a database of 115,696 individuals, which were identified to 128 groups at the genus level. It should be noted that some of these 128 taxonomic groups found at the genus level were identified only to class (e.g., Oligochaeta), order (e.g., Amphipoda), or family (e.g., Heptageniidae), in cases where further taxonomic breakdown could not be determined. Sampling occurred prior to delineation of the geospatial model, so an imbalanced 14 of the macroinvertebrate sampling sites correspond with Typology 0 (blue). In total, these sights contain 14,764 individuals, an average of 1055 per site, with the highest taxa richness of 85 . Typology 1 (red) also contains a large portion of sampling sites $(11 / 35)$, and contained 75 taxa at the genus level. This typology also has the highest macroinvertebrate count ( $74 \%$ of the whole population) at 85,270 individuals, averaging 7752 per site. With only five macroinvertebrate sampling sites, Typology 2 (yellow) has the lowest population sum (2124), averaging 425 per site. It makes up merely $2 \%$ of the entire macroinvertebrate survey, and has a taxa richness of 49. Typology 3 (green) is represented by five sites as well, and contains a count of 66 different taxa. This typology has a total of 13,538 individual macroinvertebrates that average 2708 individuals per site.

\subsection{Statistical Analysis of Macroinvertebrate Survey}

The 128 genera identified in the macroinvertebrate survey were narrowed down to 50 genera for use in the statistical analyses (Kruskal-Wallis test; Table 2), as the remaining 78 genera were found to be less common. The parameters to designate rare genera were that they occurred at $<3$ sampling sites and/or they had a sum of $\leqslant 30$ total individuals collected in the macroinvertebrate survey. The Dunn's post hoc test provides adjusted $p$ values for each typology comparison of the six genera with significant Kruskal-Wallis test results. If the adjusted $p$ value is $\leqslant 0.05$, we assume that the ranking of values is significantly different between typologies; therefore, we can infer that the genus likely favours certain typologies over others.

Table 2. Kruskal-Wallis Test results for the 50 common genera, with $H$ values, degrees of freedom (df), and $p$ values.

\begin{tabular}{cccccc}
\hline Identifier & Order & Genus & $\boldsymbol{H}$ Value & df & $\boldsymbol{p}$ Value \\
\hline G1 & Amphipoda & Amphipoda & 0.25 & 3 & 0.97 \\
G2 & Ephemeroptera & Baetidae & 4.2709 & 3 & 0.23 \\
G3 & Ephemeroptera & Baetis & 3.8312 & 3 & 0.28 \\
G4 & Trichoptera & Brachycentrus & 4.7699 & 3 & 0.19 \\
G5 & Ephemeroptera & Brachycercus & 1.03 & 3 & 0.79 \\
G6 & Ephemeroptera & Caenis & 2.2468 & 3 & 0.52 \\
G7 & Hemiptera & Callicorixa & 8.4314 & 3 & $0.04^{*}$ \\
G8 & Diptera & Ceratopogonidae & 0.0599 & 3 & 1 \\
G9 & Trichoptera & Cheumatopsyche & 2.1279 & 3 & 0.55 \\
G10 & Diptera & Chironomidae & 3.1975 & 3 & 0.36 \\
G11 & Hemiptera & Coenocorixa & 1.9423 & 3 & 0.58 \\
G12 & Hemiptera & Corixidae & 3.5733 & 3 & 0.31 \\
G13 & Lepidoptera & Crambidae & 3.8277 & 3 & 0.28 \\
G14 & Coleoptera & Dubiraphia & 8.0284 & 3 & $0.05^{*}$ \\
G15 & Odonata & Enallagma/Coenagrion & 5.0571 & 3 & 0.17 \\
G16 & Ephemeroptera & Ephemeridae/Polymitarcyidae & 2.9232 & 3 & 0.4 \\
G17 & Ephemeroptera & Ephemeroptera & 3.6787 & 3 & 0.3 \\
G18 & Ephemeroptera & Ephoron & 1.7929 & 3 & 0.62 \\
G19 & Amphipoda & Gammarus & 0.915 & 3 & 0.82 \\
G20 & Gastropoda & Gyraulus & 2.907 & 3 & 0.41 \\
G21 & Coleoptera & Haliplus & 7.9122 & 3 & $0.05^{*}$ \\
G22 & Ephemeroptera & Heptagenia & 9.5818 & 3 & $0.02^{*}$ \\
G23 & Ephemeroptera & Heptageniidae & 8.0369 & 3 & $0.05^{*}$ \\
G24 & Ephemeroptera & Hexagenia & 2.6277 & 3 & 0.45 \\
G25 & Amphipoda & Hyalella & 3.4018 & 3 & 0.33 \\
\hline
\end{tabular}


Table 2. Cont.

\begin{tabular}{cccccc}
\hline Identifier & Order & Genus & $\boldsymbol{H}$ Value & df & $\boldsymbol{p}$ Value \\
\hline G26 & Hydrachnidia & Hydrachnidia & 1.4668 & 3 & 0.69 \\
G27 & Trichoptera & Hydropsyche & 1.7677 & 3 & 0.62 \\
G28 & Trichoptera & Hydropsychidae & 2.0198 & 3 & 0.57 \\
G29 & Trichoptera & Hydroptila & 3.5846 & 3 & 0.31 \\
G30 & Trichoptera & Hydroptilidae & 2.8369 & 3 & 0.42 \\
G31 & Trichoptera & Leptoceridae & 0.2782 & 3 & 0.96 \\
G32 & Gastropoda & Lymnaeidae & 4.4723 & 3 & 0.21 \\
G33 & Diptera/Trichoptera & Nectopsyche & 2.9025 & 3 & 0.41 \\
G34 & Oligochaeta & Oligochaeta & 2.5914 & 3 & 0.46 \\
G35 & Decopoda/Malacostraca & Orconectes & 4.4706 & 3 & 0.21 \\
G36 & Gastropoda & Physa & 7.1221 & 3 & 0.07 \\
G37 & Gastropoda & Physidae & 0.9604 & 3 & 0.81 \\
G38 & Pelecypoda & Pisidium & 2.0397 & 3 & 0.56 \\
G39 & Gastropoda & Planorbidae & 3.8277 & 3 & 0.28 \\
G40 & Gastropoda & Probythinella & 7.5965 & 3 & 0.06 \\
G41 & Hemiptera & Sigara & 8.0465 & 3 & $0.05 *$ \\
G42 & Diptera & Simulium & 6.5807 & 3 & 0.09 \\
G43 & Pelecypoda & Sphaeriidae & 3.1967 & 3 & 0.36 \\
G44 & Pelecypoda & Sphaerium & 6.9774 & 3 & 0.07 \\
G45 & Gastropoda & Stagnicola & 3.7902 & 3 & 0.29 \\
G46 & Ephemeroptera & Stenacron & 2.6016 & 3 & 0.46 \\
G47 & Ephemeroptera & Stenonema & 2.2751 & 3 & 0.52 \\
G48 & Hemiptera & Trichocorixa & 0.9051 & 3 & 0.82 \\
G49 & Ephemeroptera & Tricorythodes & 2.5764 & 3 & 0.46 \\
G50 & Gastropoda & Valvata & 7.3756 & 3 & 0.06 \\
\hline
\end{tabular}

Note: * Significant results are denoted with an asterisk.

The outcomes of the Kruskal-Wallis test (Table 2) reveal significant differences in genus distribution among typologies for six of the 50 tested genera. These were Callicorixa, Dubiraphia, Haliplus, Heptagenia, Heptageniidae (identified to family), and Sigara. Subsequently, post hoc pairwise multiple comparisons were carried out using Dunn's Method on these six genera. A Bonferroni $p$ value correction for multiple paired analyses pinpoints the typologies that are different from each other (Table 3).

Table 3. Post hoc Dunn test results for each typology comparison for each genus that had a significant Kruskal-Wallis result, including the Genus Identifier, Z-Value (ZV), $p$ Value (PV), Adjusted PV (APV).

\begin{tabular}{|c|c|c|c|c|c|c|c|c|c|}
\hline \multirow{2}{*}{ Genus } & \multicolumn{3}{|c|}{3 vs. 1} & \multicolumn{3}{|c|}{0 vs. 3} & \multicolumn{3}{|c|}{2 vs. 0} \\
\hline & ZV & PV & APV & ZV & PV & APV & ZV & PV & APV \\
\hline G7 & 2.246216 & 0.0124 & 0.0741 & -1.677963 & 0.0467 & 0.2801 & 1.785511 & 0.0371 & 0.2225 \\
\hline G14 & -1.430855 & 0.0762 & 0.4574 & 0.868452 & 0.1926 & 1.0000 & 1.662240 & 0.0482 & 0.2894 \\
\hline G21 & -0.469371 & 0.3194 & 1.0000 & 1.963520 & 0.0248 & 0.1488 & 0.253711 & 0.3999 & 1.0000 \\
\hline G22 & -2.831301 & 0.0023 & $0.0139 *$ & 2.202077 & 0.0138 & 0.0830 & -1.148641 & 0.1254 & 0.7521 \\
\hline G23 & -2.634423 & 0.0042 & $0.0253 *$ & 0.671864 & 0.2508 & 1.0000 & -0.407633 & 0.3418 & 1.0000 \\
\hline G41 & -0.778480 & 0.2181 & 1.0000 & 1.138817 & 0.1274 & 0.7643 & 1.390046 & 0.0823 & 0.4935 \\
\hline \multirow{2}{*}{ Genus } & \multicolumn{3}{|c|}{0 vs. 1} & \multicolumn{3}{|c|}{2 vs. 1} & \multicolumn{3}{|c|}{2 vs. 3} \\
\hline & $\mathrm{ZV}$ & PV & APV & ZV & PV & APV & ZV & PV & APV \\
\hline G7 & 0.000000 & 0.5000 & 1.0000 & 2.167528 & 0.0151 & 0.0906 & 0.415734 & 0.3388 & 1.0000 \\
\hline G14 & -0.207490 & 0.4178 & 1.0000 & 1.810392 & 0.0351 & 0.2107 & 2.817601 & 0.0024 & 0.0145 * \\
\hline G21 & 1.669768 & 0.0475 & 0.2849 & 1.977762 & 0.0240 & 0.1439 & 2.261024 & 0.0119 & 0.0713 \\
\hline G22 & 0.090114 & 0.4641 & 1.0000 & -1.304284 & 0.0961 & 0.5764 & 0.855175 & 0.1962 & 1.0000 \\
\hline G23 & -1.341801 & 0.0898 & 0.5390 & -1.836650 & 0.0331 & 0.1988 & 0.193871 & 0.4231 & 1.0000 \\
\hline G41 & 0.576929 & 0.2820 & 1.0000 & 2.264381 & 0.0118 & 0.0707 & 2.768790 & 0.0028 & 0.0169 * \\
\hline
\end{tabular}

Note: * Significant results are denoted with an asterisk. 
After the post hoc test, it was found that four species have significant differences between typologies (Figure 6). Typology 3 and Typology 1 are significantly different for two genera, and Typology 2 and Typology 3 are significantly different for two genera. Typology 0 has the highest total counts of all four Dubiraphia, Heptagenia, Heptageniidae, and Sigara genera. Typology 3 has the second highest total for both Dubiraphia and Sigara. Typology 2 was the second highest for Heptageniidae and Heptagenia (Figure 6).

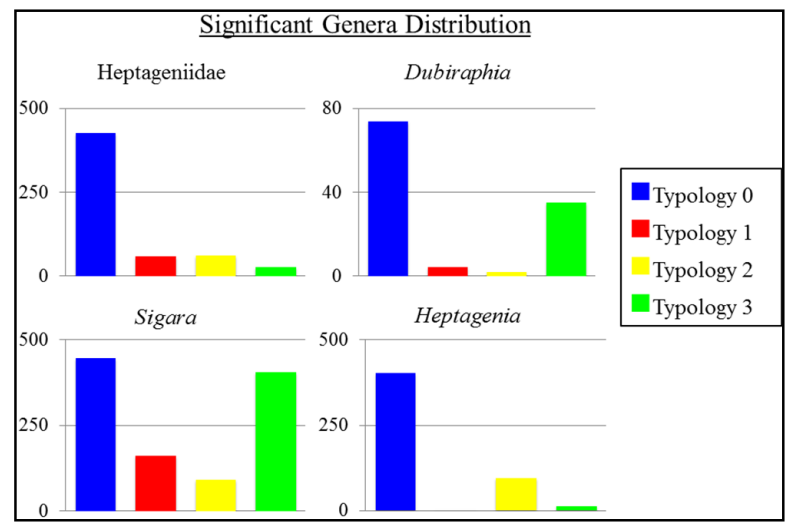

Figure 6. Bar charts depicting population distribution for the four genera found significant in Table 3, as related to the typologies.

\subsection{Ephemeroptera, Plecoptera, Trichoptera (EPT)}

The mayfly (Ephemeroptera), stonefly (Plecoptera) and caddisfly (Trichoptera) orders (EPT) are commonly used together to indicate the overall water health at a site. The groups are often sensitive to water condition and have specific habitat preferences $[3,50,51]$. The presence of a healthy EPT population indicates a healthy and well-oxygenated ecosystem, as opposed to one dominated by macroinvertebrates more tolerant to pollution (e.g., Chironomidae midges), which may indicate poor water quality $[17,52]$. The total EPT individuals, percent of the total population they represent (\% EPT), and EPT taxa richness were calculated for each typology (Figure 7). Typology 0 (blue) contains the largest total EPT population, followed closely by Typology 1 (red), while Typology 2 (yellow) contains the smallest sum. However, Typology 2 has the highest \% EPT at 52\%, followed by Typology 0 (35\%), and Typology 3 (18\%), with Typology 1 only containing 6\% EPT (Figure 7). Typology 0 has the highest EPT richness (39) of its total 85 genera. Of the 75 genera found in Typology 1, only 25 are EPT. Typology 2 has an EPT taxa richness of 18, and 49 genera overall. Typology 3 has 22 EPT taxa, and a richness of 66 genera total.

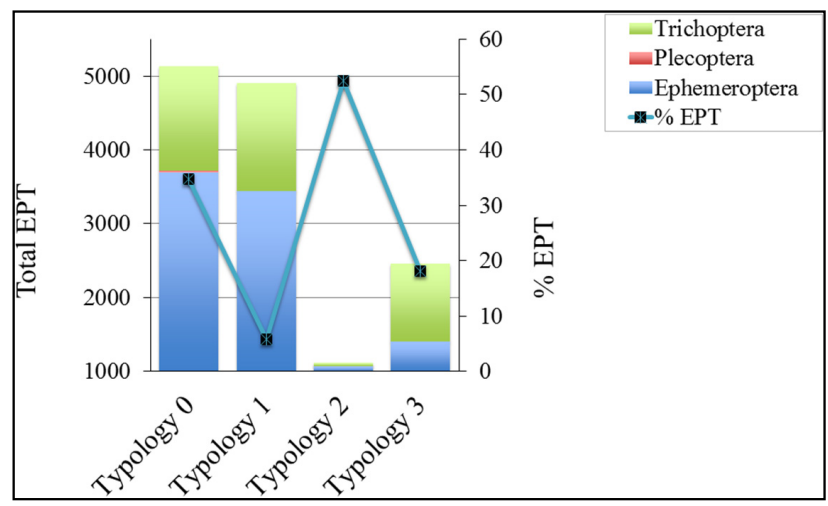

Figure 7. Total Ephemeroptera, Plecoptera, and Trichoptera (EPT) populations, and percent EPT in each typology. 


\subsection{Geomorphological Typologies}

Six of the common genera tested were found to have significant differences in distribution between typologies, signifying the predilection of several macroinvertebrates for specific geomorphic typologies in this river. These six significantly different genera are the water boatman Callicorixa, the riffle beetle Dubiraphia, the water beetle Haliplus, the water boatman Sigara, the flathead mayfly only identified to the family Heptageniidae, and those Heptageniidae further identified to the genus Heptagenia (Table 2). Four of these genera (excluding the Callicorixa and Haliplus) ranked as significant, according to Dunn's post hoc test (Table 3).

\subsubsection{Typology 0 (Blue)}

The blue typology occurs throughout the system but dominates in a few areas, most notably a large expanse south of Esterhazy, SK, stretching to just before the Manitoba border (Typology 0; Figure 3). Typology 0 is characterized as being relatively narrow, with high bank slope and fractal dimension, and no relationship with sinuosity (Table 1). Narrower reaches such as these tend to have more vegetation falling into the water, creating an ideal habitat for herbivores and detrivores [19]. Although this typology consists primarily of the functional feeding group collector gatherers $(46 \%)$, when compared to the others Typology 0 contains the most detrivores, housing $49 \%$ of them (Figure 8). The predominance of collector gatherers in this typology could be attributed to the high abundance of Chironomidae (midges) and Amphipod Hyalella, accounting for 19\% and $15 \%$ of the population respectively (Figure 9). It should be noted that Typology 0 contains the most EPT, highest EPT richness, and the second highest \% EPT of the sample (Figure 7).

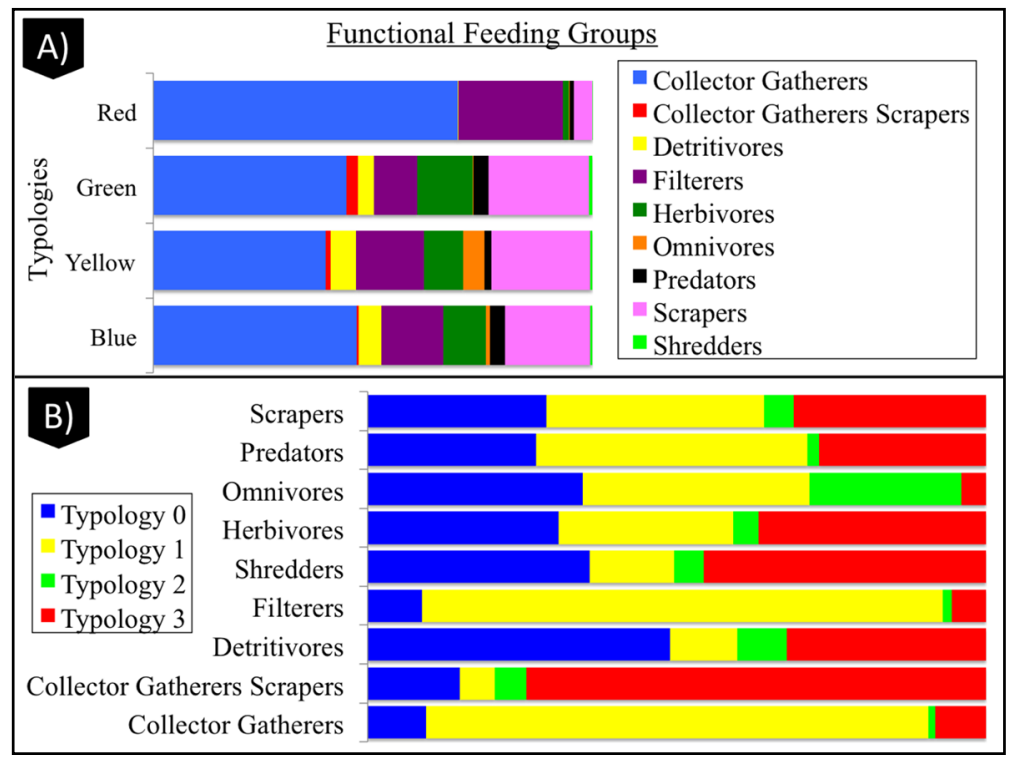

Figure 8. Proportional bar charts depicting (A) functional feeding groups contained in each typology; and (B) functional feeding group distribution amongst typologies.

The population distribution is highest in Typology 0 for all four of the genera with significant links to typologies according to the statistical analysis; thus, all four demonstrate a preference for Typology 0 (Figure 6). Of the four genera, one is a water boatman, one is a riffle beetle, and two are Heptageniidae mayflies. The mayflies (Heptageniidae; Heptagenia) are nearly exclusively found in Typology 0 , followed by Typology 2 at a distant second (Figure 6). Sometimes known as flat-headed mayflies because of adaptive general flattening and streamlining of the body, they cling to substrate in lotic streams $[17,19]$. All four of the genera showing preference to Typology 0 succeed in lotic environments. The mayfly Heptageniidae belongs to the scraper functional feeding group, which makes up $19 \%$ of 
the population in Typology 0 . They thrive in habitats where sunlight can reach, scraping biofilm and periphyton as their food source $[19,50]$. The highest concentration of the two other significant genera (Dubiraphia; Sigara) is also found in Typology 0, followed by Typology 3. The water boatman Sigara are herbivores and swimmers; they prefer areas with ample vegetation and use their modified mouthparts to pierce plant tissue [21]. The narrow reaches of Typology 0 are apt to provide access to vegetation for these herbivores. The riffle beetles Dubiraphia are collector gatherers, who cling on to substrate in lotic environments, similar to the Heptageniidae mayflies, collecting organic matter for food.

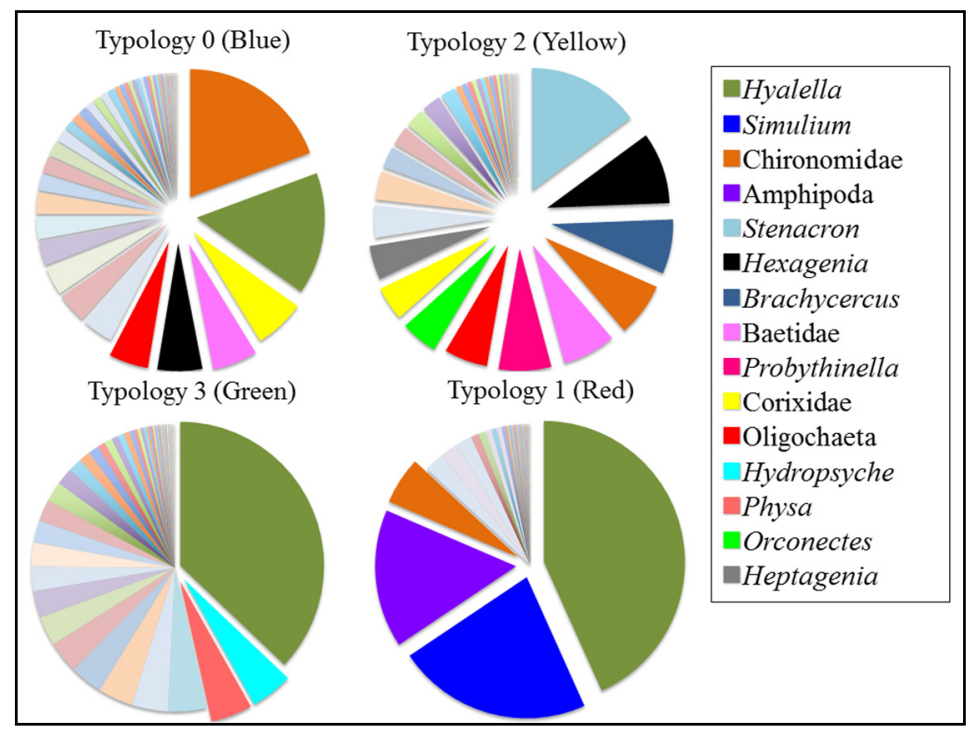

Figure 9. Population breakdown in each typology, with the most abundant genera $(\geqslant 5 \%$ of the population) named in the legend.

\subsubsection{Typology 1 (Red)}

Typology 1 dominates first at the culmination of the river until Buffalo Pound Lake (Figure 3; 1.a), then again from near Kennel, SK to the fishing lakes around Fort Qu'Appelle (Figure 3; 1.b), and again for a short stretch at the outlet of Katepwa Lake (Figure 3; 1.c). Geomorphological characteristics associated with Typology 1 are high bank slopes that are narrow with low sinuosity and low fractal dimension (Table 1). The channelized areas at the onset of the river are dominated by the red typology. It has the lowest percent of the sensitive EPT individuals, at only $6 \%$ of the total population, yet houses the highest total population at $74 \%$ of the sample (Figure 7). Correspondingly, this typology has a high taxa richness of 75, and merely 25 of them are EPT genera. Further examination of the expansive Typology 1 population at the genus level reveals that it is dominated by the amphipod Hyalella. This amphipod genus represents $43 \%$ of the total population held in Typology 1 . The Hyalella here mark the highest portion represented by one genus in any of the typologies (Figure 9).

Following Hyalella, by population size, in the red typology is the black fly larva Simulium (22\%), and those only identified to the Amphipoda order (16\%). Simulium can be found in almost any lotic water body, as they have many mechanisms to adapt to selective pressures $[53,54]$. Amphipods are very tolerant as well; Hyalella in particular has been found in extremely different climates, from Guatemala to the Northwest Territories [55]. Out of all four typologies, Typology 1 appears to have the most imbalanced distribution and least complex community, dominated by the tolerant amphipods and black fly larvae (Figure 9). Typology 1 also consists mostly of the collector gatherer functional feeding group $(69 \%)$, followed by filterers $(24 \%)$, and scrapers $(4 \%)$, with very few representatives of the other groups relative to its large population (Figure 8). As compared with the other typologies, Typology 1 contains the majority of the collector gatherers (81\%) and filterers (84\%), as well as the most predators $(44 \%)$, omnivores $(37 \%)$, and scrapers $(35 \%)$ of any typology. This is not surprising due 
to the large population held within this typology, as compared to the other three. The second highest EPT population is found here; nevertheless, it has the lowest \% EPT (Figure 7). It also contains few of the four genera found to be statistically linked to typology choice, indicating these specialized genera prefer geomorphic regions different to that of Typology 1 (Figure 6). In combining all of these indices, Typology 1 seems to house the least healthy macroinvertebrate population. It is dominated by less sensitive genera, which could result from nearby anthropogenic influences on the geomorphology.

\subsubsection{Typology 2 (Yellow)}

Typology 2 dominates the most in two separate stretches, first south of Kenlis, SK and again at Hyde, SK (Figure 3; 2.a; 2.b) It has high sinuosity and fractal dimension, with a negative relation to width, and no relation to slope (Figure 3; Table 1). Although Typology 2 houses the smallest population at merely $2 \%$ of the total population (and only five sample sites), it has the highest \% of EPT individuals. The intolerant EPT orders represent a notable 52\% of the Typology 2 population, indicating healthy water and habitat quality (Figure 7). At the genus level, the yellow typology consists mostly of Stenacron (mayfly; 15\%) and Hexagenia (mayfly; 9\%), followed by $7 \%$ each of Brachycercus (caddisfly), Chironomidae (midge), Baetidae (mayfly), and Probythinella (snail). With a fairly proportional distribution of the remaining genera, Typology 2 appears to have the most even taxa makeup of all four typologies; no single genus takes obvious dominance over the others, as is the case with Hyalella in Typology 1 (Figure 9). It contains predominantly collector gatherers (39\%), scrapers $(29 \%)$, and filterers (16\%). Within its small population, Typology 2 has $25 \%$ of the total omnivores (Figure 8).

\subsubsection{Typology 3 (Green)}

The green typology is characterized by large stream width (Table 1), and correspondingly consists mostly of the large water bodies (Buffalo Pound Lake, Pasqua Lake, Echo Lake, and Mission Lake) as well as areas scattered throughout the system (Figure 3; 3.a; 3.b). Typology 3 contains $12 \%$ of the total population within its five sampling sites, 18\% of which are EPT. When examining Typology 3 at the genus level, it contains mostly the amphipod Hyalella (37\%), followed by a fairly proportional distribution with Hydropsyche (caddisfly) and Physa (snail) at 5\%, and Valvata (snail), Chironomidae (midge), Corixidae (water boatmen), Baetidae (mayfly), and Oligochaeta (worms) at 4\% each. Besides a large amount of Hyalella, this typology has one of the more even taxa distributions, second to Typology 2 (Figure 9). In regards to functional feeding groups, the green typology has mostly collector gatherers (44\%), followed by scrapers (23\%), and herbivores (13\%; Figure 8$)$. When compared to the other typologies, Typology 3 contains the most collector gatherer scrapers (74\%), shredders $(46 \%)$, and herbivores (37\%); it also has the least omnivores $(4 \%)$. Two of the four genera that were revealed to be significantly linked to the typologies (Dubiraphia; Sigara) shared population distribution attributes, with the highest amount of both found in Typology 0, followed by Typology 3 (Figure 6). The water boatman Sigara has very similar numbers within both typologies, indicating it prefers both Typology 0 and 3 (446 individuals were collected in Typology 0, and a close 406 in Typology 3). As herbivores, Sigara need access to plants, and as swimmers, they would do well in the wide streams found in Typology 3. The riffle beetles Dubiraphia more heavily favour Typology 0 (74 individuals), with Typology 3 holding second place with 35 individuals.

\section{Conclusions}

A need for rapid and visual methods of river assessment has been identified, especially those capable of reflecting and adjusting to local stream variability [56]. Within current systems of understanding fluvial macroinvertebrates, there is a lack of comprehensive watershed approaches. The geospatial model here fills the gap in understanding river typologies and benthic macroinvertebrate distributions. The use of typologies in this study resulted in the successful classification the Qu'Appelle River by similarities in geomorphology and provided a useful model to be used as a reference for 
these geomorphic characteristics. Geospatial models have the potential to be applied to larger rivers, and to be a predictive method for macroinvertebrate habitat. The geospatial model here was further used as a means to reveal relationships between macroinvertebrate distribution and geomorphology. The effectiveness of geomorphology as a potential means of identifying macroinvertebrate habitat in a more efficient manner has been proven in this way. Certain genera in the Qu'Appelle River are significantly linked to specific regions with similar geomorphic characteristics, showing potential for the use of this geospatial model as a means of pinpointing where certain macroinvertebrates can be found. This research has been an important step in revealing significant relationships between geomorphology and benthic macroinvertebrate community in a fluvial system. We recognize that additional data would help the analysis and complement the results discussed in this study. Whereas in this study, the geospatial data was extracted at a very fine resolution of $50 \mathrm{~m}$ intervals along the river, faunistic sampling was carried out only at certain stations. Future studies will include not only geomorphological variables but also biological and physical variables extracted using different methods. A water quality model of the Qu'Appelle River is currently being developed, which will provide water temperatures and dissolved oxygen concentrations at $50 \mathrm{~m}$ intervals along the river. Bathymetric surveys of the river are also planned, which will provide water depths and substrate types at the same fine-scale resolution.

The model would be valuable to use prior to, or in lieu of field data collection. Through gaining understanding into the basic geomorphic makeup of the river before sampling, choosing sampling sites can be a more informed process. Since geomorphology drives sediment and contaminant transport, geomorphic typology maps could be a valuable tool to strategically locate new monitoring stations. Macroinvertebrates are established as indicators of environmental health, because they often respond more quickly than other groups, like fish, to ecosystem degradation and contaminants [17,18]. Understanding how geomorphology influences macroinvertebrates can be applied further up the food chain as well, as energy and contaminants move bottom up. Geomorphic structure and instream habitats are key limiting factors for freshwater fish, but it can be hard to pinpoint habitat preferences throughout their life stages [57]. Macroinvertebrates are important food sources for fish, and are also heavily influenced by geomorphic variables; incorporating macroinvertebrates may help to refine fish studies [2,57]. The geomorphic model used in this study is valuable for the sustainable preservation and management of rivers, which requires an understanding of the geomorphological factors that drive species distributions.

Acknowledgments: We thank the Saskatchewan government for supporting this manuscript preparation through its Fish and Wildlife Development Fund (contract number RE3607), and support for data collection through grants provided by the Prairie Adaptation Research Collaborative and Water Security Agency. D. Parker provided identification of the macroinvertebrate taxa, and D. Schulz, K. Kirkham, and C. Markel assisted field collection.

Author Contributions: Anna Meissner performed data analysis and prepared the manuscript; Meghan Carr delineated the model and contributed to some figures; Iain Phillips collected and provided macroinvertebrate data and contributed to the editing of the manuscript; and Karl-Erich Lindenschmidt contributed to the development of the model and editing of the method and manuscript.

Conflicts of Interest: The authors declare no conflicts of interest.

\section{References}

1. Larsen, J.; Birksl, H.J.B.; Raddum, G.G.; Fjellheim, A. Quantitative Relationships of Invertebrates to $\mathrm{pH}$ in Norwegian River Systems. Hydrobiologia 1996, 328, 57-74. [CrossRef]

2. Whiles, M.R.; Brock, B.L.; Franzen, A.C.; Dinsmore, S.C. Stream Invertebrate Communities, Water Quality, and Land-Use Patterns in an Agricultural Drainage Basin of Northeastern Nebraska, USA. Environ. Manag. 2000, 26, 563-576. [CrossRef] [PubMed]

3. Graf, W.; Murphy, J.; Zamora-Muñoz, C.; López-Rodríguez, M. Distribution and Ecological Preferences of European Freshwater Organisms; Pensoft Publishers: Sofia, Bulgaria, 2008. 
4. Altermatt, F.; Seymour, M.; Martinez, N. River Network Properties Shape $\alpha$-Diversity and Community Similarity Patterns of Aquatic Insect Communities across Major Drainage Basins. J. Biogeogr. 2013, 40, 2249-2260. [CrossRef]

5. Barton, D.R.; Farmer, M.E.D. The Effects of Conservation Tillage Practices on Benthic Invertebrate Communities in Headwater Streams in Southwestern Ontario, Canada. Environ. Pollut. 1997, 96, 207-215. [CrossRef]

6. Morrissey, C.A.; Boldt, A.; Mapstone, A.; Newton, J.; Ormerod, S.J. Stable Isotopes as Indicators of Wastewater Effects On the Macroinvertebrates of Urban Rivers. Hydrobiologia 2013, 700, 231-244. [CrossRef]

7. Dufrêne, M.; Legendre, P. Species Assemblages and Indicator Species: The Need for a Flexible Asymmetrical Approach. Ecol. Monogr. 1997, 67, 345-366. [CrossRef]

8. Bonada, N.; Rieradevall, M.; Prat, N.; Resh, V.H. Benthic Macroinvertebrate Assemblages and Macrohabitat Connectivity in Mediterranean-Climate Streams of Northern California. J. N. Am. Benthol. Soc. 2006, 25, 32-43. [CrossRef]

9. Kubosova, K.; Brabec, K.; Jarkovsky, J.; Syrovatka, V. Selection of Indicative Taxa for River Habitats: A Case Study on Benthic Macroinvertebrates Using Indicator Species Analysis and the Random Forest Methods. Hydrobiologia 2010, 651, 101-114. [CrossRef]

10. Bovee, K.D.; Lamb, B.L.; Bartholow, J.M.; Stalnaker, C.B.; Taylor, J.; Henriksen, J. Stream Habitat Analysis Using the Instream Flow Incremental Methodology; U.S. Geological Survey, Biological Resources Division Information and Technology Report: Fort Collins, CO, USA, 1998.

11. Gore, J.A.; Layzer, J.B.; Mead, J. Macroinvertebrate Instream Flow Studies after 20 Years: A Role in Stream Management and Restoration. Regul. River 2001, 17, 527-542. [CrossRef]

12. Parasiewicz, P.; Dunbar, M.J. Physical Habitat Modelling for Fish-A Developing Approach. Large River 2001, 12, 239-268.

13. Sanz-Ronda, F.J.; López-Sáenz, S.; San-Martín, R.; Palau-Ibars, A. Physical Habitat of Zebra Mussel (Dreissena Polymorpha) in the Lower Ebro River (Northeastern Spain): Influence of Hydraulic Parameters in Their Distribution. Hydrobiologia 2014, 735, 137-147. [CrossRef]

14. Breiman, L. Random Forests. Mach. Learn. 2001, 45, 5-32. [CrossRef]

15. Calow, P. A Method for Determining the Surface Areas of Stones to Enable Quantitative Estimates of Littoral Stone Dwelling Organisms to Be Made. Hydrobiologia 1972, 40, 37-50. [CrossRef]

16. Cooper, C.M.; Testa, S., III. A Quick Method of Determining Rock Surface Area for Quantification of the Invertebrate Community. Hydrobiologia 2001, 452, 203-208. [CrossRef]

17. Merritt, R.W.; Cummins, K.W.; Hunt, K. An Introduction to the Aquatic Insects of North America; Kendall/Hunt Publishing Company: Dubuque, IA, USA, 1996.

18. Ernst, A.G.; Warren, D.R.; Baldigo, B.P. Natural-Channel-Design Restorations that Changed Geomorphology Have Little Effect on Macroinvertebrate Communities in Headwater Streams. Restor. Ecol. 2012, 20, 532-540. [CrossRef]

19. Allan, J.D.; Castillo, M.M. Stream Ecology; Springer Science \& Business Media: Dordrecht, The Netherlands, 2007.

20. Dollar, E.S.J.; James, C.S.; Rogers, K.H.; Thoms, M.C. A Framework for Interdisciplinary Understanding of Rivers as Ecosystems. Geomorphology 2007, 89, 147-162. [CrossRef]

21. Dodds, W.K.; Whiles, M.R. Freshwater Ecology: Concepts and Environmental Applications of Limnology; Academic Press: San Diego, CA, USA, 2010.

22. Vannote, R.R.; Minshall, G.W.; Cummins, K.W.; Sedell, J.R.; Cushing, C.E. The River Continuum Concept. Can. J. Fish. Aquat. Sci. 1980, 37, 130-137. [CrossRef]

23. Walters, D.M.; Leigh, D.S.; Freeman, M.C.; Pringle, C.M. Geomorphology and Fish Assemblages in a Piedmont River Basin, U.S.A. Freshw. Biol. 2003, 48, 1950-1970. [CrossRef]

24. Holyoak, M.; Leibold, M.A.; Holt, R.D. Metacommunities: Spatial Dynamics and Ecological Communities; University of Chicago Press: Chicago, IL, USA, 2005.

25. Rodríguez-Iturbe, I.; Valdés, J.B. The Geomorphologic Structure of Hydrologic Response. Water. Resour. Res. 1979, 15, 1409-1420. [CrossRef]

26. Carrara, F.; Altermatt, F.; Rodríguez-Iturbe, I.; Rinaldo, A. Dendritic Connectivity Controls Biodiversity Patterns in Experimental Metacommunities. Proc. Natl. Acad. Sci. USA 2012, 109, 5761-5766. [CrossRef] [PubMed] 
27. D'Ambrosio, J.L.; Williams, L.R.; Witter, J.D.; Ward, A.D. Effects of Geomorphology, Habitat, and Spatial Location on Fish Assemblages in a Watershed in Ohio, USA. Environ. Monit. Assess. 2009, 148, 325-341. [CrossRef] [PubMed]

28. Lindenschmidt, K.-E.; Long, J. A GIS Approach to Define the Hydro-Geomorphological Regime for Instream Flow Requirements Using Geomorphic Response Units (GRU). River Syst. 2013, 20, 261-275. [CrossRef]

29. Milner, V.S.; Gilvear, D.J. Characterization of Hydraulic Habitat and Retention across Different Channel Types: Introducing a New Field-Based Technique. Hydrobiologia 2012, 694, 219-233. [CrossRef]

30. Charlton, R. Fundamentals of Fluvial Geomorphology; Routledge: Abingdon, UK, 2008.

31. Mollard, J.D. Morphological Study of the Upper Qu'Appelle River; Friends of Wascana Marsh: Regina, SK, Canada, 2004.

32. Nature Conservancy Canada. Qu'Appelle River Valley. Available online: http://www.natureconservancy.ca/ en/where-we-work/saskatchewan/our-work/qu-appelle_river_valley.html (accessed on 10 October 2015).

33. Clifton Associates Ltd. Upper Qu'Appelle Water Supply Project: Economic Impact and Sensitivity Analysis; Water Security Agency: Regina, SK, Canada, 2012.

34. Saskatchewan Watershed Authority. Getting to the Source Upper Qu'Appelle River and Wascana Creek Watersheds Source Water Protection Plan; Upper Qu'Appelle River and Wascana Creek Watersheds Advisory Committees: Regina, SK, Canada, 2008.

35. Pittman, J.; Pearce, T.; Ford, J. Adaptation to Climate Change and Potash Mining in Saskatchewan: Case Study from the Qu'Appelle River Watershed; Climate Change Impacts and Adaptation Division, Natural Resources Canada: Ottawa, ON, Canada, 2013.

36. MathSoft Inc. Mathcad v.15; MathSoft Inc.: Cambridge, MA, USA, 2012.

37. Güneralp, İ.; Abad, J.D.; Zolezzi, G.; Hooke, J. Advances and Challenges in Meandering Channels Research. Geomorphology 2012, 163-164, 1-9. [CrossRef]

38. Ahnert, F. Einführung in Die Geomorphologie; Verlag Eugen Ulmer: Stuttgart, Germany, 2015.

39. Lüderitz, V.; Kunz, C.; Wüstemann, O.; Remy, D.; Feuerstein, B. Typisierung und Bewertung für die leitbildorientierte Sanierung von Altwässern. In Flussaltwässer: Ökologie und Sanierung; Lüderitz, V., Langheinrich, U., Kunz, C., Eds.; Vieweg + Teubner: Wiesbaden, Germany, 2009; pp. 91-168.

40. Zumbroich, T.; Müller, A. Das Verfahren der Gewässerstrukturkartierung. In Strukturgüte von Fließgewässern: Grundlagen und Kartierung, 1st ed.; Zumbroich, T., Müller, A., Günther, F., Eds.; Springer-Verlag: Heidelberg, Germany; Berlin, Germany, 1999; pp. 97-121.

41. Schumm, S.A. The Fluvial System; John Wiley \& Sons: New York, NY, USA, 1977; p. 338.

42. Shen, X.H.; Zou, L.J.; Zhang, G.F.; Su, N.; Wu, W.Y.; Yang, S.F. Fractal Characteristics of the Main Channel of Yellow River and Its Relation to Regional Tectonic Evolution. Geomorphology 2011, 127, 64-70. [CrossRef]

43. Knighton, D. Fluvial Forms and Processes: A New Perspective; Routledge: New York, NY, USA, 1998.

44. Schuller, D.J.; Rao, A.R.; Jeong, G.D. Fractal Characteristics of Dense Stream Networks. J. Hydrol. 2001, 243, 1-16. [CrossRef]

45. R Development Core Team. R: A language and Environment for Statistical Computing; R Foundation for Statistical Computing: Vienna, Austria, 2012; Available online: https:/ /www.r-project.org/ (accessed on 10 September 2015).

46. Legendre, P.; Legendre, L. Numerical Ecology, 3rd ed.; Elsevier: Amsterdam, The Netherlands, 2012.

47. Dosdall, L.M.; Lehmkuhl, D.M. Stoneflies (Plecoptera) of Saskatchewan. Quaest. Entomol. 1979, 15, 3-116.

48. Clifford, H.F. Aquatic Invertebrates of Alberta; The University of Alberta Press: Edmonton, AB, Canada, 1991.

49. Webb, J.M. The Mayflies of Saskatchewan. Master's Thesis, University of Saskatchewan, Saskatoon, SK, Canada, 2002.

50. O'Laughlin, K. The Streamkeeper's Field Guide: Watershed Inventory and Stream Monitoring Methods; Adopt-A-Stream Foundation: Washington, DC, USA, 1996.

51. Karaus, U.; Larsen, S.; Guillong, H.; Tockner, K. The Contribution of Lateral Aquatic Habitats to Insect Diversity along River Corridors in the Alps. Landsc. Ecol. 2013, 28, 1755-1767. [CrossRef]

52. Mandaville, S.M. Benthic Macroinvertebrates in Taxa Tolerance Values, Metrics, and Protocols; Project H-1; Soil and Water Conservation Society of Metro Halifax: Halifax, NS, Canada, 2002.

53. Eymann, M. Flow Patterns Around Cocoons and Pupae of Black Flies of the Genus Simulium (Diptera: Simuliidae). Hydrobiologia 1991, 215, 223-229. [CrossRef] 
54. Eymann, M.; Friend, W.G. Behaviors of Larvae of the Black Flies Simulium Vittatum and S. Decorum (Diptera: Simuliidae) Associated with Establishing and Maintaining Dispersion Patterns on Natural and Artificial Substrates. J. Insect Behav. 1988, 1, 169-186. [CrossRef]

55. Government of Canada Fisheries and Oceans. Manual for the Culture of Selected Freshwater Invertebrates; Lawrence, S.G, Ed.; Department of Fisheries and Oceans Freshwater Institute: Winnipeg, MB, Canada, 1981.

56. Doll, B.A.; Jennings, G.G.; Spooner, J.; Penrose, D.L.; Usset, J.L. Evaluating the Eco-Geomorphological Condition of Restored Streams Using Visual Assessment and Macroinvertebrate Metrics. J. Am. Water Resour. Assoc. 2015, 51, 68-83. [CrossRef]

57. D'Ambrosio, J.L.; Williams, L.R.; Williams, M.G.; Witter, J.D.; Ward, A.D. Geomorphology, Habitat, and Spatial Location Influences on Fish and Macroinvertebrate Communities in Modified Channels of an Agriculturally-Dominated Watershed in Ohio, USA. Ecol. Eng. 2014, 68, 32-36. [CrossRef]

(C) 2016 by the authors; licensee MDPI, Basel, Switzerland. This article is an open access article distributed under the terms and conditions of the Creative Commons by Attribution (CC-BY) license (http:/ / creativecommons.org/licenses/by/4.0/). 